\title{
In vitro regeneration of Anacardium occidentale from shoot tip and basal part
}

\author{
Bi Tra Jean-Innocent NANTI*1, Yah Gwladys GNAMIEN ${ }^{2}$, Tchoa KONE ${ }^{1}$, \\ Brahima André SOUMAHORO ${ }^{3}$, Mongomaké KONE ${ }^{1}$
}

\author{
${ }^{1}$ Université Nangui Abrogoua, UFR des sciences de la Nature, Laboratoire de Biologie et Amélioration des Productions Végétales, 02 BP \\ 801 Abidjan 02 (Cote d'Ivoire) \\ ${ }^{2}$ Université Jean Lorougnon Guédé de Daloa. UFR Agroforesterie, Laboratoire de Physiologie Végétale. BP 150 Daloa. (Côte d’Ivoire) \\ ${ }^{3}$ Ecole Normale Supérieure d'Abidjan, 08 BP 08, Tel (225)22488854, Fax (225)22444232 \\ *Corresponding Author
}

\begin{abstract}
The culture of cashew (Anacardiumoccidentale L.) is the main source of income for populations in northern Côte d'Ivoire, with an estimated production of 725000 tonnes in 2017, but the average yield remains low likely due to the lack of elite planting material and hence use of unselected plant material by mostfarmers. For mass propagation of such a material, in vitro methods are necessary. Unfortunately, it is difficult to obtain surviving explants from mature plants grown in the field, whereby explants from seedlings obtained by in vitro germination are the most suitable for micropropagation of cashew.The objective of this study was to propagate under in vitroconditionselite plants of Anacardiumoccidentaleto be used as planting material. In Nangui Abrogoua University laboratory,shoot tip and basal part explants derived from vitroplants of 16-day-old were transferred onto Murashige and Skoog (MS) medium containing different concentrations of cytokinins.After one month of culture, the induced shoots were placed onto different strengths of MS medium withvarious concentrations of sucrose and auxin. The highest number of buds (9) was recorded with the basal explants on medium supplemented withThidiazuron (TDZ) at $0.01 \mathrm{mg} / \mathrm{l}$. The highest shoots $(3 \mathrm{~cm})$ were obtained with these sameexplantson a medium without growth regulators. A1/2 MS with $60 \mathrm{~g} / \mathrm{l}$ of sucrose and $5 \mathrm{mg} / \mathrm{l}$ of IBA induced the highest rooting percentage (72\%) and number of roots (4 roots) in a short time (16 days).
\end{abstract}

Keywords-Anacardiumoccidentale; culture in vitro;rooting; shoot tip;basal explants.

\section{INTRODUCTION}

The cashew tree (Anacardiumoccidentale), from the family Anacardiaceae is a plant native to Northeastern Brazil, whose culture contributes to the socio-economic development of several countries in the world (Bezerraet al., 2007). The nut that is the main commercial product of the cashew tree (Martinezet al., 2011) is used in agri-food, cosmetology, medicine, the automobile industry as brake oil and clutch (Aliyuand Awopetu, 2007)and in household firewood (Ricau and Konan,2010).In Côte d'Ivoire, cashew nut has quickly attracted interest so that the country has become since 2015 the world's largest producer before India with 702000 tonnes of cashew(MINAGRI, 2016).

Despite the importance of production, the yields of walnuts in the Ivorian orchards remain low, of the order of 350 to $500 \mathrm{~kg} / \mathrm{ha}$, because of plantations created with unimproved plant material and unsuitable peasant farming practices (Djahaet al., 2012).

In order to provide farmers with high yielding plant material, various methods of vegetative propagation have been tested in cashew. Grafting is the most common technique (Behrens, 1996). However, this technique is slow and allows only a relatively limited production of plant material. For mass production of plant material, it is necessary to use technologies such as in vitro culture,to allow the production of clones in large quantities and in a relatively short time, the year round. However, micro propagation of cashew, as for other Anacardiaceae, faces difficulties.One of the major constraints during in vitro culture of cashew is the high production of secondary metabolites as a result of organ harvesting injuries (Mantellet al., 1998). Indeed, the oxidation of these compounds causes organ browning and necrosis on the culture medium (Jha, 1988; Daset al., 1996).As well, 
explants collected in the field survived with difficulty because of the high level of disinfectant required for their decontamination (Das et al., 1996., Silva et al., 2011).These authors recorded $3 \%$ and $25 \%$ survival for shoot tips and nodal explants of field-grown twigs, respectively, subjected to thorough sterilization. Most explants that survived after disinfection turned brown or necrotic by 20 days of culture (Rodrigues, 1995;Daset al., 1996).Often, micropropagation from mature tree explants is affected by excessive contamination, phenolic exudation, slow growth, difficulty in elongation and rooting of micro shoots(Thanishkaet al., 2009).

$\begin{array}{ccccc}\text { Explants } & \text { excised } & \text { from } & \text { in } & \text { vitro } \\ \text { germinatedseedlings } & \text { were } & \text { most } & \text { suitable } & \text { for }\end{array}$
micropropagation of elite cashew as reported by numerous.Thimmappaiah (2004),Keshavachandran (1997),Keshavachandran and Riji (2005)andSija(2016)reported that shoot tips, nodal segments and cotyledonary nodes taken from in vitro raised seedlings were used to establish in vitro cultures. The highest number of buds was obtained by cotyledonary nodes with intact cotyledons on MS medium containing $2.25 \mathrm{mg} / \mathrm{l} \mathrm{BA}$ and $0.2 \mathrm{mg} / \mathrm{l}$ IBA.However, there are no reports to date of the use of basal part explant (explant with cotyledons and roots obtained after removal of apical dominance) for the production of leaf shoots. Although there are protocols for in vitro regeneration of cashew trees, rooting remains difficult. The quantity of sugar used for rhizogenesis has always been $30 \mathrm{~g} / \mathrm{l}$. In Côte d'Ivoire, no studies onin vitro culture of local cashew tree varieties have been initiated. The general objective of this work was to establish an effective protocol for regeneration of cashew tree varieties produced in Côte d'Ivoire fromshoot tip and basal parts.

\section{MATERIALS AND METHODS}

Cashew mature seed were collected in farmer fields of Gohitafla in West central Cote d'Ivoire (transitional woodland savannah with blocks of semideciduous forests). The seeds were surface sterilized during $1 \mathrm{~min}$ in $70 \%(\mathrm{v} / \mathrm{v})$ ethyl alcohol and $30 \mathrm{~min}$ in $7 \%$ (w/v) calcium hypochlorite solution (Figure $1 \mathrm{a}$ ), they were rinsed and immersed in sterile distilled water for 72 hours (Figure 1b). After imbibition, seeds were rinsed four times and surface sterilized a second time during $1 \mathrm{~min}$ in $70 \%$ (v/v) ethyl alcohol, $15 \mathrm{~min}$ in $7 \%(\mathrm{w} / \mathrm{v})$ calcium hypochlorite solution (Figure 1c) and rinsed abundantly with sterile distilled water. After this double sterilization, seed coats were removed (Figure 1d) andthe almonds (Figure 1d) were cut in halfs lengthwise. The embryo- containing portion was cultured in jars with30 ml MS medium (Murashige and Skoog, 1962) with $30 \mathrm{~g} / \mathrm{l}$ sucrose and $2 \mathrm{~g} / \mathrm{l}$ activated charcoalfor 16 days.The $\mathrm{pH}$ of the medium was adjusted to 5.8 and $3 \mathrm{~g}$ ofphytagel were added.

\section{Induction, multiplication and rooting of shoots from shoot tip and basal partexplants}

The seedlings obtained in vitro after 16 days of almond culture on MS media (Figure 2a) were used as explants source. The mother plants were cut to obtain two types of organ fragments namely the basal part explant (consisting of roots and cotyledons) and the shoot tip. Both types of organ fragments were cultured separately on MS culture medium for bud induction (Figure $2 \mathrm{~b}$ and $\mathrm{c}$ ). The experiment was repeated three times with 10 replicated explants per organ type.

To optimize budinduction, the explants consisting of basal parts and shoot tips were cultured on media supplemented with benzylaminopurine (BAP) and kinetin at $0 ; 1 ; 2 ; 4 ; 6 \mathrm{mg} / 1$ orthidiazuron (TDZ) at $0 ; 0.001 ; 0.01$; 0.1 and $1 \mathrm{mg} / \mathrm{l}$. The experiment was repeated three times for each concentration of each cytokinin used, with 10 explants per repetition.

After 30 days of culture, the shoots induced were separated from the explants and then transplanted on to rooting medium, which contained IBA and/or NAA at 0 ; 2.5 and $5 \mathrm{mg} / \mathrm{l}$. The rooting experiments were repeated three times for each concentration of each auxin used, with 10 explants per repetition.

In addition, MS mineral elementswere tested at full-, half( $1 / 2)$ ora quarter $(1 / 4)$ strength to stimulate rooting, with experiments repeated three times per strength each with 10 explants.

Finally, various amounts of sucrose (30, 40 and 60 $\mathrm{g} / \mathrm{l}$ )were also tested for rooting,with experiments repeated three times per sucrose concentration, each with 10 explants.

All cultures were incubated under $100 \mu \mathrm{Em}^{-2} . \mathrm{sec}^{-1}$ light for a photoperiod of $12 \mathrm{~h}$ at $25^{\circ} \mathrm{C}$ and a hygrometry of $70 \%$.

\section{Experimental design and data analysis}

The experiments were carried out in a completely randomized design with ten replicates and each individual treatment was repeated three times. Bud frequency, number of buds per explant and frequency of rhizogenesis were submitted to analysis of variance (ANOVA) to detect significant differences between means of each growth regulator and explant type. Means differing significantly were compared using Newman-Keuls multiple range test at 
International Journal of Environment, Agriculture and Biotechnology, 5(3)

May-Jun, 2020 / Available: https://ijeab.com/

the $5 \%$ probability level using statistical software program $\quad$ Statistica version 7.1.
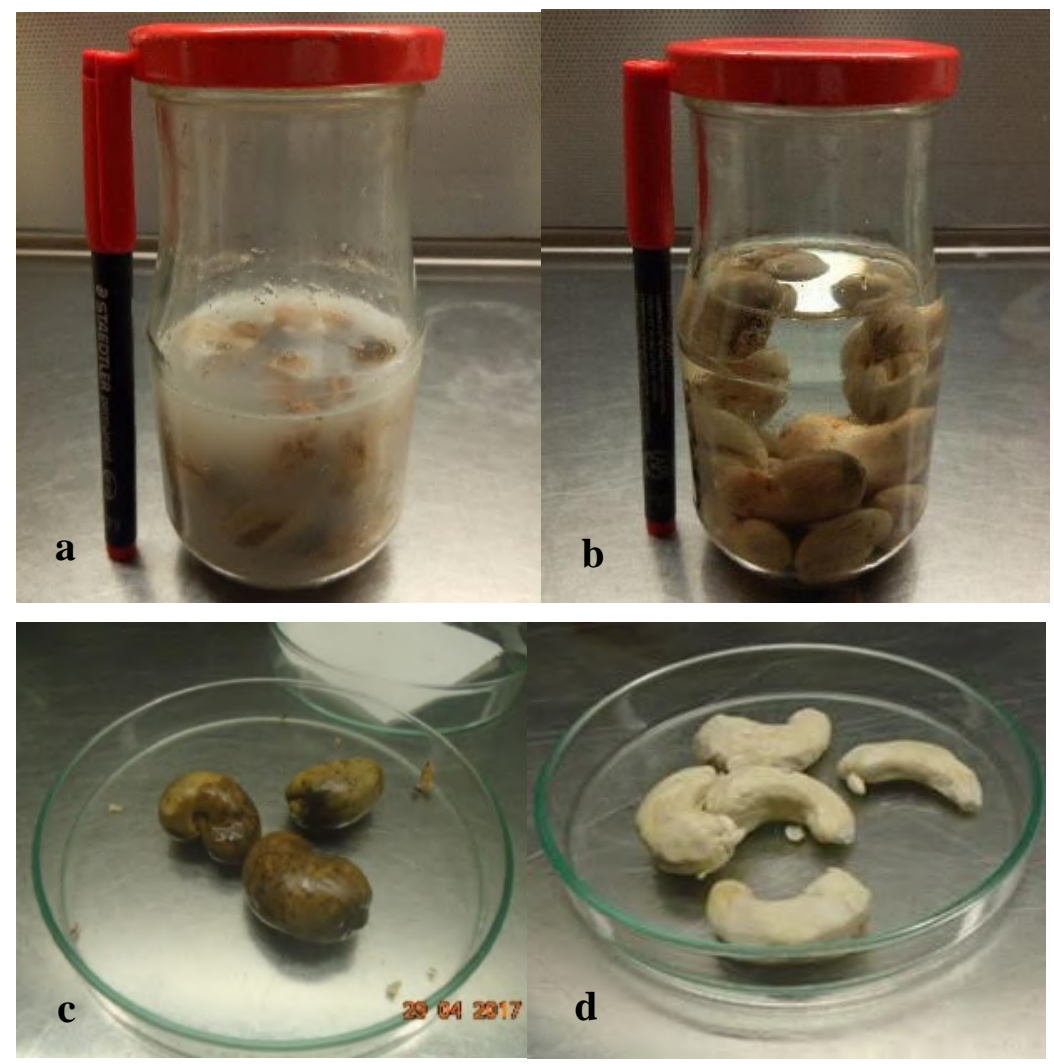

Fig.1: Steps of seeds disinfection

(a): Soaking the seeds in the disinfectant; (b): imbibition in distilled water; (c): Disinfected seed; (d): Decoated seed(almond)

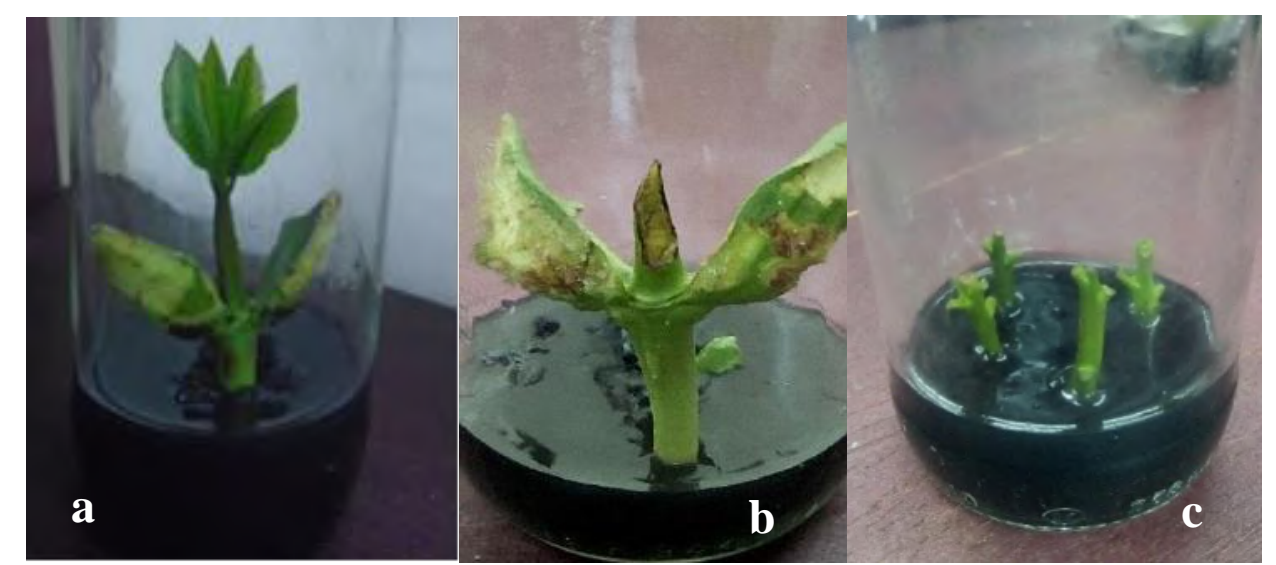

Fig.2: Transfer of explants on culture media. (a) 16 days old seedling ; (b): basal part; (c): shoot tip 


\section{RESULTS}

\section{Bud Induction}

After four weeks of culture of the basal part explants and shoot tips on media (Figure 3) containing different concentrations of cytokinins, budding percentages were influenced by the type of explants $(\mathrm{P} \leq 0.001)$, as recorded in Table 1 , but did not vary according to the type of cytokinins and their concentrations. Conversely, the number of buds and average height of shoots were all significantly influenced by the type of explants, the hormones used, and their concentrations (Table 1). The highest budding percentages (greater than 70\%) were obtained with the basal part explants.

An interaction effect was observed between the various factors $(\mathrm{P} \leq 0.001)$. Thus, the highest number of buds per explant( 9 buds) was obtained with the basal explants on the medium supplemented with an optimum at $0.01 \mathrm{mg} / \mathrm{l}$ of TDZ, whilethe lowest average numbers of buds $(<2)$ were obtained with the shoot tip explants, whatever the concentration of growth regulators used. On the other hand, the highest sizes of shoots were induced by the basal part explants and decreased with increasing hormone concentration.

\section{Rooting of shoot buds}

After four weeks of culture, the shoots induced were transferred onto MS medium supplemented with IBA or NAA, alone or in combination, for rooting. After 45 days of culture, shoots induced roots (Figure 4).The percentage of rooting and the average number of roots were influenced by the hormones used(Table 2). The highest percentage of rooting $(24 \%)$ was obtained with IBA-NAAfollowed by $5 \mathrm{mg} / \mathrm{l} \operatorname{IBA}(18 \%)$ and finally $2.5 \mathrm{mg} / \mathrm{lIBAand} 5 \mathrm{mg} / \mathrm{l}$ NAA $(6 \%)$. The medium devoid growth regulator did not favor root formation.
The roots appeared earlier on media containing IBA-NAA (2.5 mg/l each auxin) and $2.5 \mathrm{mg} / 1 \mathrm{IBA}$ in contrast to the medium containing $5 \mathrm{mg} / \mathrm{l} \mathrm{NAA}$.

Higher numbers of roots were induced in presence of IBA, but the highest number of roots (4 roots per shoot) was obtained on medium supplemented with a combination IBA-NAA(2.5 mg/l for each auxin), followed by $5 \mathrm{mg} / \mathrm{l}$ IBA with 3.8 roots per explant, and then media containing respectively $2.5 \mathrm{mg} / \mathrm{l} \mathrm{IBA}$ and $5 \mathrm{mg} / \mathrm{l} \mathrm{NAA}$ with about 2 roots per shoot.

As IBA favored the formation of a large number of roots, it was used at the same concentrations with different strengths of MS mineral elements and different concentrations of sucrose to optimize rhizogenesis. The results for this experiment are shown in Table 3. The percentage of rooting increased proportionally with IBA concentration regardless of thestrength of MS mineral elements and the concentration of sucrose used. The highest percentage of rooting $(72 \%)$ and the greatest number of roots (4 roots per shoot bud) were obtained on the $1 / 2 \mathrm{MS}$ containing $60 \mathrm{~g} / \mathrm{l}$ sucrose and supplemented with $5 \mathrm{mg} / \mathrm{l}$ IBA.

The mean time to rooting was influenced by thestrength of MS mineral elements $(\mathrm{P}=0.044)$ and IBAconcentration ( $\mathrm{P} \leq 0.001)$, but sucrose concentration had no effect on this parameter $(\mathrm{P}=0.439)$, even if an interaction effect of the three factors was observed $(\mathrm{P} \leq$ 0.001). The roots appeared earlier (about 17 days) on the shoots transferred on $1 / 2$ MS medium containing $60 \mathrm{~g} / 1$ sucrose and with $5 \mathrm{mg} / 1 \mathrm{IBA}$. The longest time to root formation (23 days) occurred on the same medium but supplemented with $2.5 \mathrm{mg} / \mathrm{l} \mathrm{IBA}$.

The results revealed a very large influence of thestrength of MS mineral elements $(\mathrm{P}=0.004)$, sucrose ( $\mathrm{P}$ $=0.001)$ and auxin concentrations $(\mathrm{P} \leq 0.001)$ of the medium concerning the number of roots. This parameter evolves proportionally with the concentration of IBA. 




Fig.3: Shootbuds induced from different explants. (a): shoot buds on the basal part; $(b)$ : shoot buds on shoot tip.

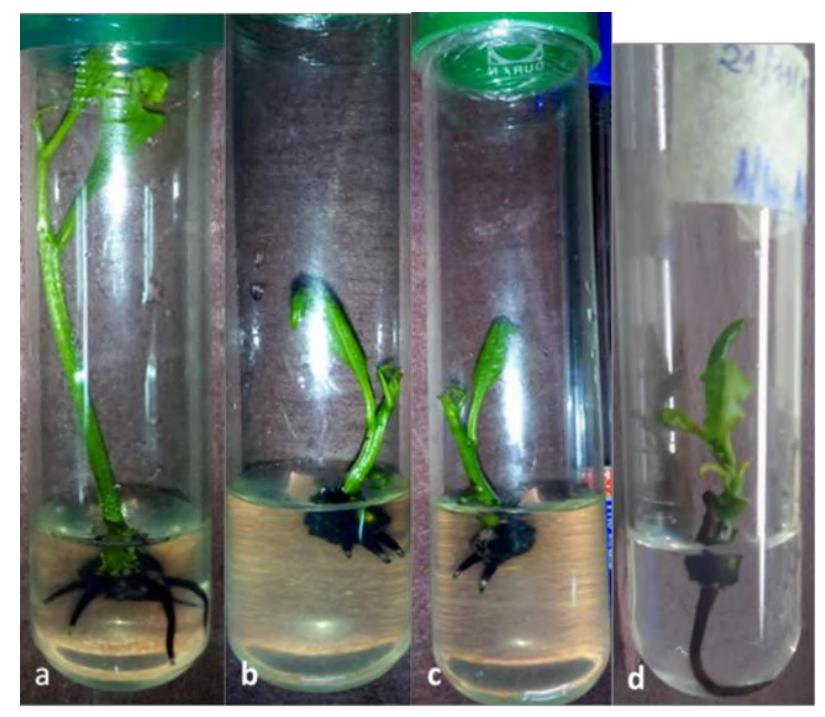

Fig.4: Rooting of shoot buds on different culture media

(a): $1 / 2 M S+60 \mathrm{~g} / \mathrm{l}$ of sucrose $+5 \mathrm{mg} / \mathrm{l}$ of IBA; $(\mathrm{b}): 1 / 4 \mathrm{MS}+60 \mathrm{~g} / \mathrm{l}$ of sucrose $+5 \mathrm{mg} / \mathrm{l}$ of IBA; $(\mathrm{c}): 1 / 4 \mathrm{MS}+40 \mathrm{~g} / \mathrm{lof}$ sucrose + $5 \mathrm{mg} / \mathrm{l}$ of IBA; $(\mathrm{d}): 1 / 4 \mathrm{MS}+40 \mathrm{~g} / \mathrm{l}$ of sucrose $+2.5 \mathrm{mg} / \mathrm{l}$ of $I B A$

Table 1. Responses of explants basal part and shoot tip on SM medium supplemented with various concentrations of cytokinins

\begin{tabular}{|c|c|c|c|c|c|}
\hline Xplants & Hormones & Concentrations (mg/l) & $\begin{array}{l}\text { Percentage of } \\
\text { bud induction } \\
(\%)\end{array}$ & $\begin{array}{l}\text { Average } \\
\text { number of buds } \\
\text { / explant }\end{array}$ & $\begin{array}{l}\text { Average bud } \\
\text { size } \\
(\mathrm{cm})\end{array}$ \\
\hline & Control & 0 & $78 \pm 5,68^{\mathrm{a}}$ & $4,40 \pm 0,14^{\mathrm{f}}$ & $2,8 \pm 0,23^{\mathrm{a}}$ \\
\hline & BAP & 1 & $78 \pm 5,68^{a}$ & $5,47 \pm 0,19^{e}$ & $\begin{array}{l}2,60 \pm 0,28 \\
\text { ab }\end{array}$ \\
\hline & & 2 & $81 \pm 5,01^{a}$ & $6,33 \pm 0,25^{\mathrm{cd}}$ & $2,67 \pm 0,3^{a b}$ \\
\hline & & 4 & $81 \pm 5,01^{\mathrm{a}}$ & $6,63 \pm 0,29^{c}$ & $\begin{array}{l}2,47 \pm 0,28 \\
\mathrm{ab}\end{array}$ \\
\hline & & 6 & $72 \pm 6,68^{a}$ & $5,87 \pm 0,29$ de & $\begin{array}{l}1,76 \pm 0,28 \\
\mathrm{~cd}\end{array}$ \\
\hline Basal part & Kinetin & 1 & $75 \pm 7,87^{\mathrm{a}}$ & $8,07 \pm 0,40^{b}$ & $2,65 \pm 0,36$ \\
\hline
\end{tabular}




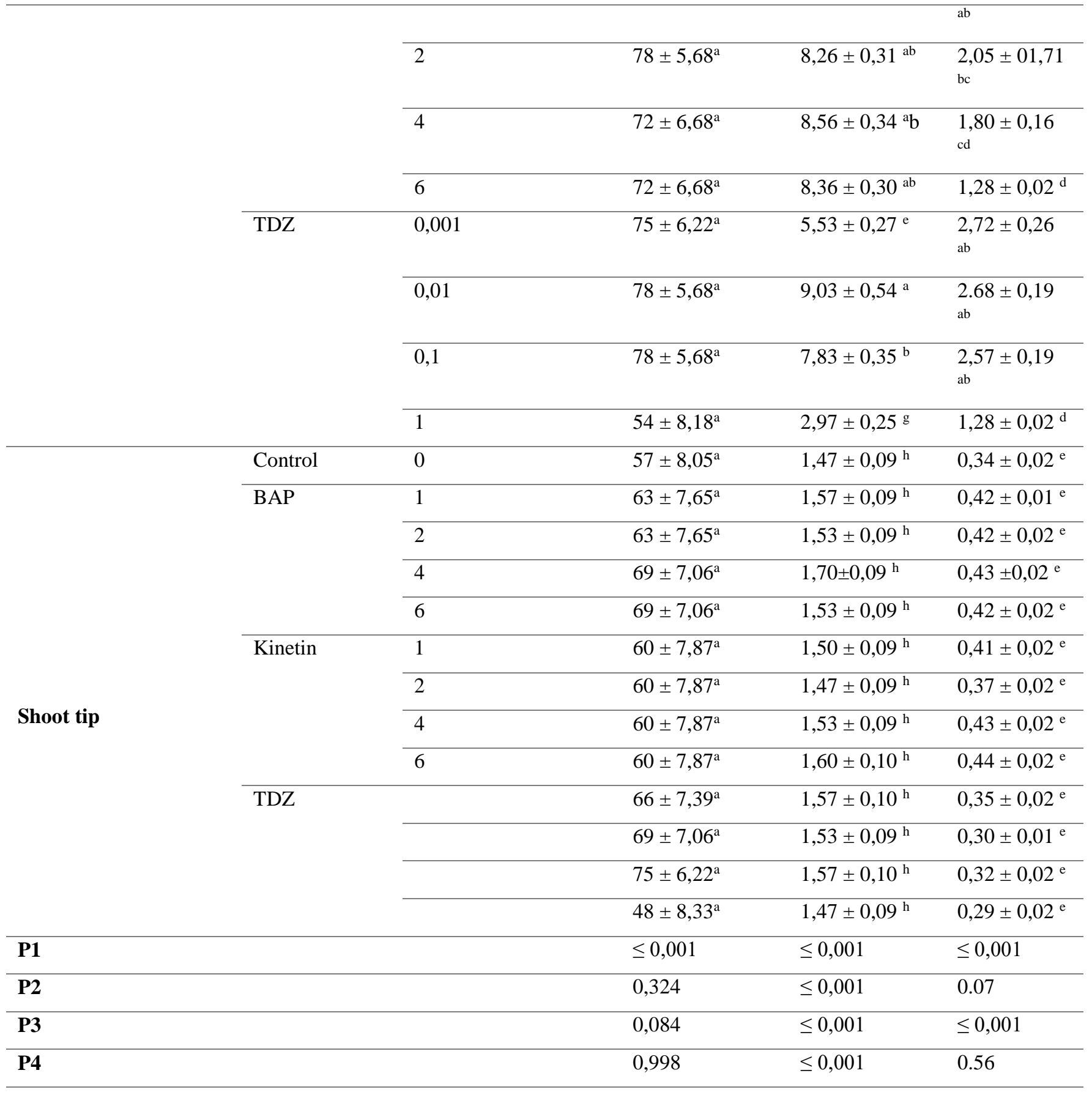

Mean in a column followed by a common letter are not significantly different at $5 \%$ level (Newman-Keuls test) (average \pm standard error).

(P1): probability of the type of explant; (P2): probability of hormone (P3): probability of hormone concentrations; (P4): Probability of explant-hormone-hormone concentration interaction

The control consists of medium without growth regulators 
International Journal of Environment, Agriculture and Biotechnology, 5(3)

May-Jun, 2020 / Available: https://ijeab.com/

\begin{tabular}{lllll}
\hline Hormones & Concentrations (mg/l) & $\begin{array}{l}\text { Percentage of } \\
\text { rooting }(\%)\end{array}$ & mean time rooting (days) & $\begin{array}{l}\text { Average number of } \\
\text { roots } / \text { explant }\end{array}$ \\
\hline Control & 0 & $0 \pm 0^{\mathrm{c}}$ & - & $0 \pm 0^{\mathrm{c}}$ \\
\hline IBA & 2,5 & $6 \pm 4,17^{\mathrm{b}}$ & $33,67 \pm 0,45^{\mathrm{b}}$ & $2,83 \pm 0,21^{\mathrm{b}}$ \\
& 5 & $18 \pm 6,68^{\mathrm{ab}}$ & $34,4 \pm 0,41^{\mathrm{ab}}$ & $3,8 \pm 0,27^{\mathrm{a}}$ \\
\hline NAA & 2,5 & $0 \pm 0^{\mathrm{c}}$ & - & $0 \pm 0^{\mathrm{c}}$ \\
\hline NAA+IBA & 5 & $6 \pm 4,17^{\mathrm{b}}$ & $35,3 \pm 0,31^{\mathrm{a}}$ & $2,53 \pm \pm^{\mathrm{b}}$ \\
& 5 & $0 \pm 0^{\mathrm{c}}$ & - & $0 \pm \pm^{\mathrm{c}}$ \\
\hline P1 & $2,5+2,5$ & $24 \pm 7,39^{\mathrm{a}}$ & $33,66 \pm 0,44^{\mathrm{b}}$ & $4 \pm 0,27^{\mathrm{a}}$ \\
\hline P2 & & 0,092 & $\leq 0,001$ & $\leq 0,001$ \\
\hline P3 & 0,001 & $\leq 0,001$ & $\leq 0,001$
\end{tabular}

Mean in a column followed by same letter are note significantly different at 5\% level (Newman-Keuls test) (average \pm standard error)P1): probability of hormones; (P2): probability of hormone concentration; (P3): probability of hormonehormone concentration interaction

The control consists of medium without growth regulators

Table 3. Effect of different strengths of MS mineral elements, sucrose and IBA on rooting

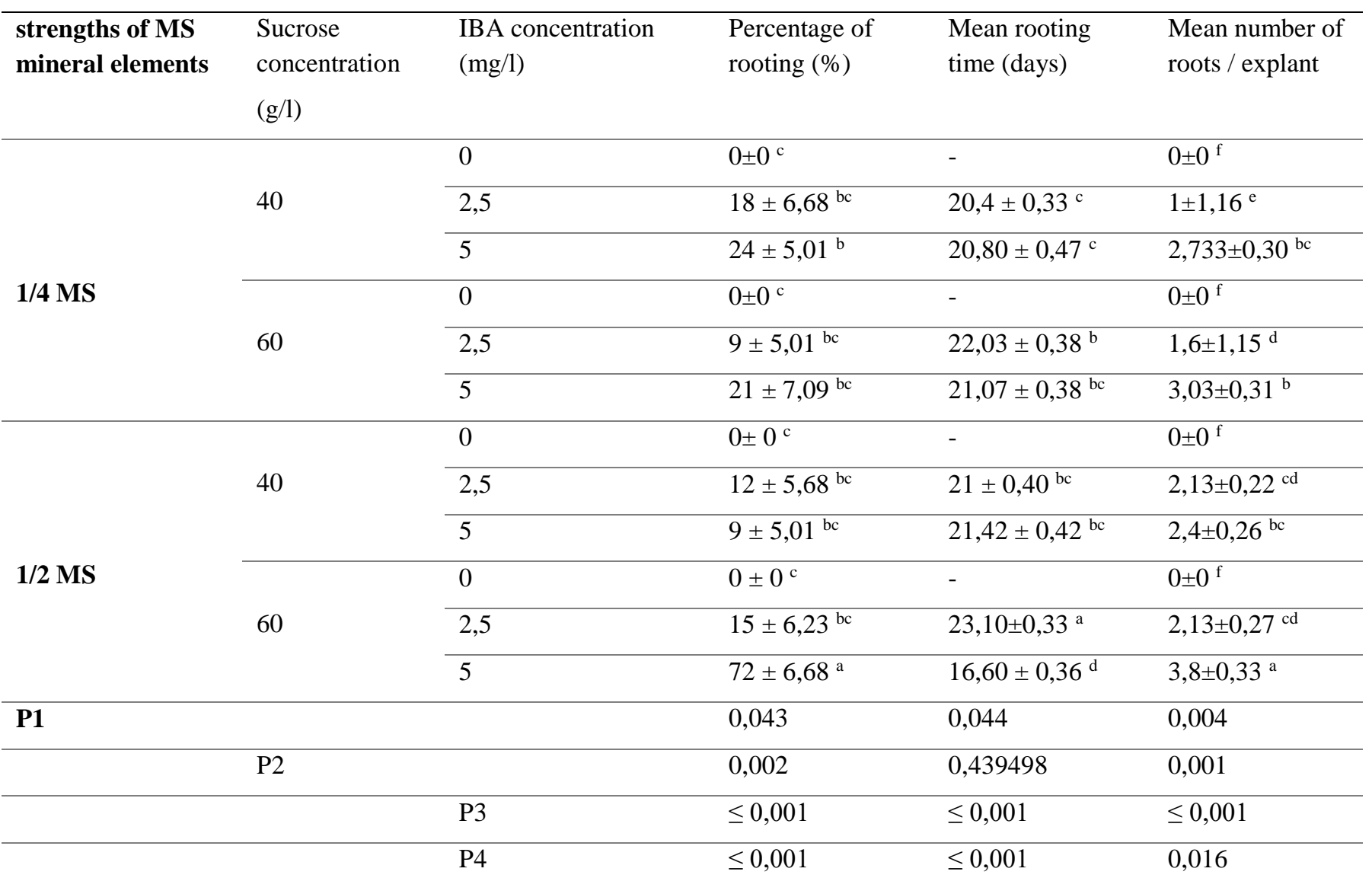

Mean in a column followed by same letter are note significantly different at $5 \%$ level (Newman-Keuls test) (average \pm standard error) 
(P1): probability of the strengths of MS mineral elements; (P2): probability of sucrose concentrations; (P3): probability of IBA concentrations; (P4): Probability of interactions strengths of MS mineral elements - sucrose concentrations concentration of IBA

\section{DISCUSSION}

Cytokinins are used for their effectiveness in inducing buds from explants. Thus, BAP, kinetin and TDZ have all favored bud induction. However, high concentrations of cytokinins have inhibited bud production and subsequent development. The number of buds is a function of the type of explants and of the cytokine in concentrations used. TDZ has a high potential for bud induction, and higher number of buds with TDZ, unlike BAP, were also obtained when studying the clonal propagation of cashew by tissue culture(Mneney and Mantell, 2002).

The highest number of buds obtained with the basal part explants could be due to the larger meristematic zone at the cotyledonary node, unlike the shoot tip where this zone is less important. A higher potential of bud induction (12 buds) by cotyledonary nodes compared toother explants on MS medium was reported on cashew tissue culture (Das, 1996). and on the regeneration of Dacryodes edulis(Youmbi and Benbadis, 2001). Similar numbers of buds(9 /explant)were obtained from cotyledonary nodes on Anacardiumoccidentale culture(Rodrigues, 1995).Cotyledonary nodes with intact cotyledons obtained from in vitro germinated seedlings (mature seed) of cashew showed multiple shoot induction on MS. After 5-6 subcultures at monthly intervals, the shoot-bud proliferation increased and as many as 40-60 shoots could be obtained in a span of 3-4 months (Thimmappaiah, 1997).

Shoots of large size were induced from basal explants, perhaps due to the presence of cotyledons and roots, as cotyledons are nutrient reserve structures for subsequent growth of the seedling, while roots allow the explant to uptake nutrients from the medium to provide energy to the young growing shoots. The basal explants on a medium with high concentrations of cytokinin induced small shoots,probably because the very high concentrations of cytokinins inhibited cell division and was thus unfavorable to the elongation of young shoots of cashew. These results are in agreement with those of (Mneney and Mantell, 2002) who worked on the clonal propagation of cashew by tissue culture and showed that high concentrations of BAP or TDZ in the medium inhibited shoot elongation. Other authors also reported that BAP and TDZ inhibit bud growth, when these cytokinins are used in very high amounts in the organogenesis medium(Thanishka et al., 2009).

\section{Rooting of shoot buds}

In vitro rooting depends on the nature and concentration of auxin, but may also depend on the concentration of mineral elements and sugar in the culture medium. IBA and NAA are the most used auxins for rooting young shoots of cashew. The highest percentages of rooting were obtained in the presence of IBA, unlike NAA. The highest percentage of rooting was obtained with a combination of IBA plus NAA, whose synergistic effect on rhizogenesis of cashewresulting in a similar percentage ofrooted shoots $(80 \%)$ were already reported whenNAA andIBA were included together in the culture medium(D'souza and D'silva 1992). A high rate of in vitro rooting of cashew shoots wasalso obtained on WPM medium supplemented with $2.5 \mathrm{mg} / 1 \mathrm{NAA}$ and IBA in combination (Thimmappaiah and Sadhana 1999). In vitro stimulation by the association of IBA+NAA has also been observed in other woody species, includingFraxinusexcelsior(Silveira and Cottignies, 1994); Quercus sp (Ostrolucka and Bezo, 1994). and Agrania spinoza(Bousselmane et al., 2001).

To optimize rooting responses IBA was used at $5 \mathrm{mg} / \mathrm{l}$ with different strengths of MS mineral elements and different concentrations of sucrose. The percentages of rooting increased in proportion with the concentration of IBA regardless of the strength of MS mineral elements and sucrose concentration used. Thus, the highest percentage of rooting (72\%) was obtained on $1 / 2 \mathrm{MS}$ containing $60 \mathrm{~g} / \mathrm{l}$ sucrose and $5 \mathrm{mg} / \mathrm{l}$ IBA. The halving of the concentrations of mineral elements of MS and the increase in the concentration of sucrose were essential in the rhizogenesis of the cashew tree during the present study. In fact, the reduction of the concentration of minerals in the medium causes a decrease in the nutritive resources of this medium.On another side, sucrose is involved in the growth equilibria and in the localization of mitoses(Jay-Allemand et Cornu, 1986). These authors state that high concentrations of sucrose, establishing high osmotic pressures, can reduce the transport of water and nutrients from the base to the aerial part.The reduction of strengths of MS mineral elements, coupled with an increase in the amount of sugar in the culture medium and therefore the reduction of nutrients to foliar organs, would result in mineral stress. The leafy shoots, to cope with this stress 
state will emit roots. Authors have also reported the induction of roots by reducing the concentration of nutrients in the medium. Likewise,other authors (Muhammad and Faheem, 2016; Evandro et al., 2017)induced rooting rates of $70 \%$ and $65 \%$ respectively in Tectonagrandis on $1 / 2 \mathrm{MS}$.In vitro best rooting (50\%) of single shoots of cashewwas also obtained on half-strength MS medium containing NAA $(2.0 \mathrm{mg} / \mathrm{l})+$ IBA $(2.0$ $\mathrm{mg} / \mathrm{l})$ [29] and in combination containing $2.5 \mathrm{mg} / 1$ each of NAA and IBA (Nair and Mohanakumaran, 1993)compared to medium supplemented with ANA or IBA alone.If during this study, the rate of rooting of the local variety (Côte d'Ivoire) of cashew tree increased when the sucrose concentration of medium is high $(60 \mathrm{~g} / \mathrm{l})$, other authors likeD'Silva and D'Souza (1992) have obtained a higher rooting rate $(80 \%)$ with other varieties on medium containing the usual concentrations of sucrose $(30 \mathrm{~g} / \mathrm{l})$. These results show that the rooting of the cashew tree would depend on the varieties. The shoots transferred on medium devoid growth regulators did not induce root. Auxins are therefore essential for rooting in vitro shoot bud of cashew

\section{CONCLUSION}

In conclusion, this study revealed that BAP, Kinetin and TDZ used at low concentrations favored the induction of a high number of buds in cashew. TDZ stimulated the highest number of shoots at $0.01 \mathrm{mg} / \mathrm{l}$ compared to the other two cytokinins. The induction of shoots depends on the type of explant, and explants from the basal part of shoots produced the largest number of shoots.

NAA and IBA induced root formation. The highest percentage of rooting was obtained on $1 / 2 \mathrm{MS}$ containing $60 \mathrm{mg} / \mathrm{l}$ sucrose and $5 \mathrm{mg} / \mathrm{l}$ IBA.

Future experiments will focus on the acclimation of the regenerated plants to in vivo conditions.

\section{REFERENCES}

[1] Aliyu O.M.\&Awopetu J.A. (2007). Assessment of genetic diversity in three populations of cashew (Anacardiumoccidentale L.) using protein-isoenzyme electrophoretic analysis. Genetic Resources and Crop Evolution, 54 : 1489-1497.

[2] Behrens R. (1996). Cashew as an agroforestry crop Prospects and potentials. Tropical Agriculture, 83p.

[3] Bezerra M.A., De Lacerda C.F., Filho E.G., De Abreu C.E.B. \&Prisco G.T. (2007). Physiology of cashew plants grownunder adverse conditions. Brazilian Journal of Plant Physiology, 19 (4), ISSN 1667-9452.
[4] Bousselmane, F., Kenny L. \&Chlyah H. (2001). Optimisation des conditions de culture pour l'enracinement in vitro de l'arganier (Arganiaspinosa L.).C R Acad Sci. Paris, 324 :995-1000.

[5] D'souza, L. \&D'silva I. (1992). In vitro propagation of Anacardiumoccidentale L. plant, Cell Tissue and Organ Culture, 29(1):1-6.

[6] Das S., Jha T.B. \& Jha S. (1996). In vitro propagation of cashew nut. Plant Cell Reports. 15(8):615-619.

[7] Djaha J.B.A., N'da A.A., Koffi E.K., Ballo C.K. \& Coulibaly M. (2012). Croissance et aptitude au greffage de deux génotypes d'anacardier (Anacardium occidentale L.) élites utilises comme porte-greffe en Côte d'Ivoire. International Journal of Biological and Chemical Science, 6 (4) : 1453-1466.

[8] Jay-Allemand C.\&Cornu D. (1986). Culture in vitro d'embryonsisolés de noyercommun (JuglansregiaL.). Annals ScienceForest, 43 (2) : 189-198.

[9] Jha T.B (1988). In vitro morphogenesis in cashew nut (Anacardium occidentale L.). Indian Journal of Experimental Biology, 26 : 505-507.

[10] Keshavachandran R. \&Riji V.S. (2005). Standardisation of in vitro micrografting techniques in cashew. In: Proceedings of National Symposium of Biotechnological Interventions for Improvement of Horticultural crops: Issues and Strategies, Kerala Agricultural University, 205p.

[11] Keshavachandran R. (2004). Report submitted to the DBT., New Delhi

[12] Mantell S., Boggett B., Bessa A., Lemos E., Abdelhad A. \&Mneney E. (1998). Micropropagation and micrografting methods suitable for safe international transfer of cashew. Proceedings of International Cashew and Coconut Conference, 1997 Dares Salaam, pp 95-107.

[13] Martinez, A., Penarredona M., Pheng B., Hoyos D., Ting J. \& Alvarez N. (2011). Global Enterprise Experience, INDICASHEW, TEAM 58, 8p.

[14] MINAGRI. (2016). Ministère de l'Agriculture. Conférence de presse : en route pour l'émergence. Auditorium de la Primature 06 Juin 2016. www.gouv.ci.

[15] Mneney E.E. \&Mantell S.H. (2002). Clonal propagation of cashew (Anacardiumoccidentale L.) by tissue culture. The Journal of Horticultural Science and Biotechnology, 77 (6) : 649-657.

[16] Muhammad A. \&Faheem A. (2016). Establishment of Embryogenic Cultures and Efficient Plant Regeneration System from Explants of Forced Softwood Shoots of Teak. Horticultural Plant Journal, 2 (5) : 293-300.

[17] Murashige T.\& Skoog F. (1962). A revised medium for rapid growth and bioassays with tobacco tissue culture. Physiology Plant, 15 : 473-497.

[18] Nair S.R. \&Mohanakumaran N. (1993). Standardisation of tissue/apical/meristem culture techniques in horticultural crops of Kerala, Final Technical Report (USDA). IN-AES343, Thiruvananthapuram, Kerala, pp 3-15.

[19] Ostrolucka M. and Bezo L. (1994). Utilisation of meristem cultures in propagation of oak (Quescus sp). Geneticiapolonica, 35 : 161-169. 
[20] Ricau P. \& Konan C. (2010). La filière anacarde en Côte d'Ivoire acteurs et organisation. Compte rendu de missions Mars-juillet 2010, 43p.

[21] Rodrigues J. (1995). Development of selection and clonal propagation techniques for multiplication of yield and anthracnose tolerant cashew (Anacardiumoccidentale L.). First Year Scientific Progress Report. EU Contract No. TS 3 CP 93-0221.

[22] Sija S.L., Potty V.P.\&Santhoshlal P.S. (2016). In Vitro Shoot Proliferation from Excised Shoot Tip and Nodal Segment of AnacardiumoccidentaleL. International Journal of Current Microbiology Applied Science, 5(3) : 635-642.

[23] Silva A.L.L., Oliveira Y. and Costa J.L. (2011). Preliminary results for genetic transformation of shoot tip of Eucalyptus salignaSm. via Agrobacterium tumefaciens. Journal of Biotectecnology and Biodiversity, 2, 1 - 6.

[24] Silveira C. \&Cottignies A. (1994). Period of harvest, sprounting ability of cuttings and in vitro plant regeneration in Fraxinus excelsior. Canadian Journal of Botany,72 : 261267.

[25] Silveira C. \&Cottignies A. (1994). Period of harvest, sprounting ability of cuttings and in vitro plant regeneration in Fraxinus excelsior. Canadian Journal of Botany,72 : 261267.

[26] Tambarussi E.V., Rogalski M., Galeano E., Gilvano M.R., Brondani G.E., De Martin V.F.,Da Silva L.A.\& Carrer H. (2017). Efficient and new method for Tectonagrandisin vitro regeneration. Crop. Breed. Appl. Biot.17: 124-132.

[27] Thanishka, V., Kottearachchi N., Attanayake D. and Jayasekera S. 2009. Callus Induction and In vitro Organogenesis in Cashew (AnacardiumoccidentaleL.) Proceedings of 9th Agricultural Research Symposium, pp 316-320.

[28] Thimmappaiah\&Shirly R. (1999). Regeneration in vitro of cashew (Anacardiumoccidentale L.). Indian Journal of Experimental Biology, 37 : 384-390.

[29] Thimmappaiah\&Shirly R.S. (1996). Micropropagation studies in cashew (Anacardium occidentale L.). National Symposium on Horticulture (souvenir), Bangalore, 65p.

[30] Thimmappaiah (1997). Ph.D. thesis, Mangalore University, India, 264p.

[31] Youmbi E. \&Benbadis A. (2001). Régénérationin vitro de plants à partir des bourgeons axillaires et apex de plantulessexuées de Dacryodes edulis (Don) Lam. Fruits, pp 333-343 